\title{
Research Methods in TEFL Studies: Descriptive Research, Case Study, Error Analysis, and R \& D
}

\author{
Haryanto Atmowardoyo \\ Universitas Negeri Makassar, Indonesia
}

\begin{abstract}
Articles published in International journals have rich potentials of learning sources since their publication has been scholarly processed through the hands of journal editors. Readers can get a lot of benefits from them. One lesson we might get is the way the writers conducted their researches. Thus, we can learn the research methods from the models found in journal articles. This paper will elaborate the research methods used in the teaching of English as a foreign language (TEFL). The elaboration is formulated from the research methods used by journal article writers around the world. A number of international journal articles in TEFL are taken as the corpus of the study. Using a grounded theory, varieties of research methods in TEFL are investigated. Among of them are case study, quasi experiment, qualitative experiment, meta analysis, descriptive research, activity theory, error analysis, $R \& D$, action research, research and development $(R \& D)$, and survey method. Due to the limited space, however, the paper will only describe four popular methods: descriptive research, case study, error analysis, and $R \& D$. The description of each method is supported with examples found in international journal articles published around the world.
\end{abstract}

Index Terms — descriptive research, case study, error analysis, R \& D, TEFL studies, journal articles

\section{INTRODUCTION}

In a previous publication, Atmowardoyo (2010) explains that research method is a systematic procedure a researcher uses to solve the defined research questions. It covers three main items: research design, data collection procedure, and data analysis all of which are usually placed in the third chapter of a thesis, dissertation, or any other form of a research report, following 'Introduction' (chapter 1) and 'Review of the Related Literature' (chapter 2). This generally becomes a very important section of research activity. A careless procedure a researcher uses will result invalid data, which in turn will result unreliable and probably harmful findings and recommendations.

Research activities are commonly directed to prove a hypothesis or to reveal a new substantive theory. In the world of scientific investigation, some experts use two different research approaches: quantitative approach and qualitative approach. Quantitative approach refers to research design involving deductive thinking to prove hypotheses which in turn will support or reject a theory. The data under analysis are quantified and, therefore, numerical in nature leading to the use of statistical formulas in the analysis. This kind of approach generates some kinds of research methods such as survey, experiments, quasi experiments, and correlation studies. Conversely, qualitative approach refers to research designs involving inductive thinking to reveal hypotheses which in turn will become a substantive theory and even a formal theory. The data under analysis are verbal description poured into field notes. The data analysis includes some steps such as coding, comparison, integration, triangulation, and interpretation. This approach comprises some methods such as phenomenology, ethnography, case study, narrative inquiry, participant observation, biographical study, and grounded theory. A new term 'QUALIATATIVE' is now introduced to accommodate the differences in the kinds of qualitative research method (Agar, 2009).

Besides quantitative and qualitative approaches, however, some research methodologists introduce a mixed approach, that is, the mixture of both quantitative and qualitative approaches used in a research project. Onwuegbuzie and Leech (2006), for examples, are two proponents who elaborated the mixed approach through an article "Linking Research Questions to Mixed Methods Data Analysis Procedures." Another proponent of mixed research method is Johnson who published an article together with Onwuegbuzie entitled "Mixed Methods Research: A Research Paradigm Whose Time Has Come" (2007). Sage Publications Inc has eventually published a journal of mixed methods under the supports of these proponents.

There are numerous books of research methodology in our library. Many research articles can also be found through the search of scientific journals. The writer can easily find articles about language studies covering studies of pragmatics, sociolinguistics, language acquisition, or psycholinguistics. It is also easy to find articles on language education through the search of journals of language teaching research. This library study examines the research methods commonly used by today's researchers in the field of language education. The result of the analysis is addressed to reveal the current practice in research tradition in this field. From this, the readers will learn different types of research methods implemented by researchers around the world.

\section{RESEARCH QuESTIONS}


This study aims to answer two questions as follows:

- What kinds of research methods are commonly applied in TEFL studies?

- How do these kinds of research methods operate to achieve the defined goals?

\section{RESEARCH METHOD}

\section{A. Source of Data}

This study involves 30 research articles in TEFL (the teaching of English as a foreign language) studies published in scientific journals from 2002 to 2017. The articles were purposively chosen to formulate condensed description about the types of research methods used in TEFL studies; as well as the procedures taken to achieve the intended research objectives.

\section{B. Data Analysis}

The articles were analyzed inductively to generate a description about the research methods employed by article writers. Adopting the qualitative research procedures suggested by Strauss and Corbin (1990), data analysis procedures consisting of open coding, axial coding, and selective coding were used. By open coding, the articles under analysis are carefully read to identify the research method applied. The focus of attention is to identify the kinds of the research method, the research objectives, the way of data collection, and the way of data analysis. These focused points are necessary to describe what, why, and how the article writers conduct their studies so as they are successful in communicating their research findings through international scientific journals. Thus, under the open coding, we give labels to any description in the articles which relate to these focused points. The result of open coding is a number of conceptual labels which are going to be used to describe the phenomena implied in the journal articles. By axial coding, we relate one conceptual label to another. One label might refer to the detail of another label or vice versa. We call the detail as the subcategory, whereas the umbrella label is called as the category. The result of axial coding is then a number of categories, and under each category are a number of subcategories.

Selective coding is the process of identifying any phenomena related to the research questions which functions to support the result of axial coding. Very often, in the process of axial coding the researcher finds incomplete categories or subcategories. By the selective coding, the researcher hopes that these incomplete categories or subcategories will be recovered.

Finishing exploring the relationship among categories and/or subcategories, a theoretical description was developed to generate the answers to the research questions: the kinds of research methods commonly used in language and literature studies, and how the methods are operated.

\section{FINDINGS}

\section{Types of Research Methods in TEFL Studies}

As a part of findings of this library research, under this section the writer describes briefly the kinds of research methods that may be beneficial in TEFL studies. The kinds of methods include the followings: descriptive research, case study, error analysis, and R \& D. These four types are amongst the popular methods employed by today's researchers in TEFL studies. Thus, from analysis of the journal articles, the writer generates explanation of these four methods followed by examples of each. Other methods which are also potential for TEFL studies are still left unexplored due to the limited space. These methods include action research, discourse analysis, meta-analysis, activity theory, survey, and program evaluation.

1. Descriptive Research: objectives, instrument, data analysis

There is an agreement among research methodologists about the term descriptive research. Descriptive research is defined as a research method used to describe the existing phenomena as accurately as possible. The word "existing phenomena" makes descriptive research contrary to experiment research which observes not only the existing phenomena, but also the phenomena after a certain period of treatment. The phenomena observed in descriptive research are already available. What is necessary for a researcher to do is collecting the available data through the use of research instruments such as test, questionnaire, interview, or even observation. The main goal of descriptive research is to describe systematically the existing phenomena under the study.

Descriptive research covers some subtypes of research methods such as survey, correlation study, qualitative study, or content analysis. These subtypes are different not in the data availability, but in their procedures of data collection and/or analysis. Thus, descriptive study may involve QUAN analysis or/and QUAL analysis. Survey, for example, is usually designed to investigate a large population's perspective about a particular event or problem. Data collection is commonly conducted through questionnaire administration, and its data analysis involves quantification. Correlation study also involves quantitative data analysis since it is designed to find out the coefficient correlation index between two prevailing variables. Content analysis may involve either QUAN or QUAL data analysis. Whereas the other three: qualitative research, ethnography, and life history tend to involve QUAL data analysis.

Examples of Descriptive Research

From the study of 30 articles published in various journals in language teaching, the writer finds out a number of 
titles developed from descriptive research. The first example is (Hassal, 2003). This study is designed to reveal the way Australian learners of Indonesian express request in everyday situation. In an attempt to answer the research problem, Hassal conducted a descriptive research involving 20 students undertaking an undergraduate degree program in Bahasa Indonesia at an Australian University. Dividing the students into Proficiency Group and Low Linguistic Proficiency Group, the researcher collected the required data by means of interactive role play. Judgment of appropriacy was determined through a process of discussion with BI native speaker informants consisting of 18 Indonesian students. The result of the study reveals that both groups favor the same request type known as query preparatory. The subjects, however, were reported that they used a different modal verb to perform their request; used Want statements and Hint statements more than native Indonesians do; and used elided imperative less often.

The second example is Lee (2007). This study is designed to answer the following two questions: (1) "What is the nature of teacher feedback in the Hong Kong writing classroom?" and (2) "To what extent is teacher feedback exploited for assessment for learning purpose?" Lee employed a descriptive research to find out the answer to the defined questions. This descriptive research involves the collection of written feedback, interviews with teachers either face-toface or through email, and focus group interviews. Data analysis involves analysis of teachers' written feedback, translation, transcription, coding, and summary of email interview data. The study finally reveals the answers as follows: (1) Teacher feedback practices are influenced by institutional context and values, possibly making it hard for them to use feedback to realize the potential of assessment for learning. Teacher feedback is not fully utilized to benefit student learning.; (2) Teacher can be helped to re-examine the goals of writing instruction, how writing is taught, and how assessment should reflect the instructional goals and link to the pedagogical activities.

The third example is Kikuchi (2009), a descriptive research to describe two points: (1) the salient demotivating factors in Japanese classrooms; and the issues should teachers consider to reduce demotivation in Japanese school English classrooms. This qualitative research involves five university students as the main participants. Data were collected through direct and email interview and questionnaires. Data analysis procedure was adapted from Huberman and Miles (1994) including data collection, data display, data reduction, and conclusion drawing and verification. This study reveals a list of demotivating factors related to teachers, school facilities, students' experience; student attitude, group attitude, interference of other languages, and text books.

The fourth example is Griffiths (2008). This is a descriptive research to find out the ways how good language learners (GLL) use language learning strategies. The study involved 131 students being asked to complete questionnaire known as ELLSI (English Language Learning Strategy Inventory). The result was analyzed into mean frequencies and statistical differences by the means of SPSS and Mann-Whitney U test). The findings reveal that higher level students do report significantly more frequent use of strategies or activities consciously chosen for the purpose of regulating their own language learning, in particular: strategies to manage their own learning (meta-cognitive); to expand their vocabulary; to improve their knowledge of grammar; to make use of resources such as TV or movies; to involve all language skills (reading, writing, listening, speaking).

Another example is Bade (2008). This study was conducted to investigate student attitudes towards grammar in order to integrate this into the 20-week course entitled "English for Living and Working in New Zealand". The aims of the course were to enable the student to actively and appropriately participate in New Zealand community and workplace settings. This is a descriptive research involving 14 students enrolled for the course. They are from many different countries and aged from 20 to 68. Data were collected through a questionnaire consisting of 20 questions, 15 which were focused, open-ended questions. Five others were Yes/No questions. The students on this course showed overwhelming desire to be taught grammar, to concentrate on accuracy, and to have their errors corrected.

\section{Case Study}

Case study can also be classified as a descriptive research since it is designed to describe the existing condition of a particular case. However, it is different in the subject or phenomena under the study. A case study researcher focuses on a particular case with special characteristics. Thus, case study refers to an in-depth examination about an individual, a unit of organization, or a particular event with special characteristics. In the studies of TEFL, numerous researchers have made use of case study method to construct theoretical descriptions based on the phenomena related to English language teaching and learning. From the examination of 30 articles, six of them (20\%) are case studies.

Types of Case Study: Positive, Neutral, and Negative

Observing the case study methods used in TEFL studies, three different types of case study emerged: positive case study, neutral case study, and negative case study. A positive case study is the one using a positive case as the phenomena under observation. The epistemological basis for a positive case study is that "a good theory can be generated from the best practice". The studies of good English language learners, effective EFL teachers, and effective EFL program management are those of positive case study. The focus of the study is the interrelations of variables contributing to the success of an individual or a group of learners, teachers, or a unit of organization.

In TEFL studies, the emergence of positive case studies was inspired by Rubin (1975) with an article entitled "What can we learn from good language learners." Since then, numerous articles making use of good language learners (GLL) have been published. Griffith (2008) edited a book covering 23 articles about GLL. Haryanto (1999) has also ever conducted a case study to find out the answers to the following question: "How does motivation of a good Indonesian EFL learner (Indra) operate to achieve success of EFL learning in Indonesian context?" and "What are the learning 
strategies performed by Indra as a good Indonesian EFL learner?" This is a case study to an outperforming Indonesian EFL learner, Indra, a pseudonym of a student of senior high school in Indonesia. Data were collected through the process of in-depth-interview, participant observation, and document examination. Data analysis was conducted using the grounded theory adopted from Strauss and Corbin (1990) including open coding, axial coding, selective coding; and story line development. The results of this study has been reported in two articles: Haryanto (2007 a) focusing on the literature review of good language learner studies; and Haryanto $(2007 \mathrm{~b})$ focusing on the role of motivation and language learning strategy as the core factors influencing the success of English language learning. Three main categories emerged from this study. First, motivation and learning strategies revealed the main factors influencing the success in English learning; second, motivation fluctuation was influenced by some other factors; and third, dichotomy of motivation as intrinsic and extrinsic was not clear. Instead, the mixture of both kinds of motivation had lead to the learning strategies leading to success of Indra in EFL learning.

In recent years, a number of studies of effective or successful EFL teachers have also been made. Hatifah (2017) explores successful EFL teachers in terms of their verbal cues in classroom interaction. Weda (2016) observes the students' voice about the characteristics of good English teachers at Indonesian secondary schools. Similarly, Khaerati (2016) and Asriati (2015) have also made use of effective EFL teachers as the central phenomena under observation. Both of them try to identify the qualities attributable to effective EFL teachers in Indonesian context.

Neutral case study is a term used to refer to a case study research whereby the researchers do not consider the characteristics of the case under study. The objective of the study is to explain the phenomena in a particular context. The first example is Wai King Tsang (2004), who conducted a research to investigate the role of teachers' personal practical knowledge in interactive decision making for three pre-service non-native ESL teachers. This is a case study of three pre-service non-native ESL teachers. Data were collected by asking the three student teachers to write a language learning/teaching autobiography, a statement of their philosophy and teaching expectations, and a description of their favorite teachers at the beginning of their Practice Teaching course. After-class interviews, non-participant observations, and a video-based method of eliciting introspective data were conducted to triangulate the findings. Inductive analysis approach with content analysis method was applied to analyze the collected data. The findings of this study reveal that teachers apply their personal practical knowledge not only in making interactive decisions, but also in teachers' other decision-making processes. Three implications were proposed: first, bringing personal practical knowledge to the foreground helps optimize the accessibility to, or potential application of, such knowledge in the decision-making process; second, post reflection provides an opportunity for teachers to orchestrate both old and new aspects of personal practical knowledge and raises consciousness of situations in which instructional decisions, planned or immediate, are called for; and third, the study show teachers' maxims to be an effective operationalization of the concept of personal practical knowledge.

The second example is Nixon \& McCay (2007), a case study investigating the ways how three elementary teachers (Samantha, Amy, and Natalie) summatively assessed their own students' written work over a three and one-half month period. Data collection was conducted through interview and classroom observation, as well as analysis of artifacts (rubrics, student reflections, assignments, year and unit plans, and professional journals). Data analysis was conducted through holistic data analysis: reading, thinking aloud, coding, and drawing inferences. The result of the study reveals that these three teachers develops four conversational routines or structures in assessing their students' written work, namely: group gossiping or spectating; reading/ rereading; deliberating/ reframing; and collaboratively creating.

The third example of case study is Basturkmen, Helen and Marilyn Lewis (2002). The study set out to investigate the following questions: "How do three students conceptualize and assess their success and the reasons for it on an EAP writing course?" and "How do the students' perspectives relate to the perceptions of their teachers?" This study involves 3 female Students and 2 teachers (one male one female) as the participants. Data collection was conducted through interview and email dialogues with students. Data Analysis was conducted following analytical induction procedures: revisited the data a number of times, individually and together, looking for salient themes and patterns which were then commented on in the researchers' words. The findings of the study maintain that the three students have different views of success; teachers' perceptions of their students' success vary in many respects from those of the students.

Wette (2009) can be taken as the fourth example of case study. The study was conducted to identify the curriculum making principles and practices a number of teachers were familiar with in the literature of second language teacher education.

To achieve the defined objectives, the researcher conducted what she called an interpretative case study of a number of selected teachers of English for the speakers of other languages (ESOL). In an attempt to collect the required data, seven well-qualified, experienced teachers were interviewed weekly. Their documents and materials produced over the duration of a whole were also collected. The interviews and the documents were qualitatively analyzed through the process of coding to generate categories relevant to the research questions. As a result, the case study reveals three main points. The first, the professional knowledge and experience of the study teachers was apparent in their ability to conceptualize and draft plans-in readiness in the pre-course phase, to establish rapport and diagnose learners' developmental priorities in the initial phase, and to weave a coherent curriculum from a variety of components and sources, taking into account conflicting demands and not losing sight of its global structure. The second, curriculum 
making practices are consistent with the findings of earlier relevant researches. The third, however, the curriculum making accounts of the seven teachers in this study all differ significantly from much of the advice and information offered in language teacher education literature.

In contrast to positive case study, negative case study researcher makes use of an "unexpected phenomenon" under observation. A popular case study in TEFL studies is Curtiss (1977) who successfully published a book entitled "Genie: A Psycholinguistic Study of a Modern-Day Wild Child”. She observed a 16-year girl, Genie, who was unfortunately deprived away from society since her birth. The phenomena of Genie were explored from her language development.

\section{Error Analysis}

Studies about learners' errors in their language production are actually descriptive in nature. Thus, these studies may also be covered under the term descriptive research. However, since the studies are specific in their steps of analysis, such studies are commonly categorized as error analysis.

The term error analysis (EA) was originally used to refer to language studies focusing on the linguistic errors made by second language learners. The term was popularized by Corder (1971) and Richards (1974). Since then, many researchers conducted studies about linguistic deviances produced by second language learners.

Error analysis is usually designed to identify the kinds of learners' errors in second language learning. Prior to the emergence of EA was CA (contrastive analysis) which revealed an assumption that first language interference was the dominant factor affecting the second language learners' errors. Ellis (1997: 15) argues that EA is important for three reasons: that learners' errors are of interesting phenomena raising a question of why learners make errors; that EA is useful for teachers to know what errors learners make; and that EA may actually help learners to correct their errors by themselves. Under the theory of contrastive analysis (CA), language educators predict that any L2 system that is different form L1 system will cause difficulties to the learners. However, under the theory of EA, interference is not claimed to be the only dominant factor. Another factor which is also dominant is overgeneralization, indicating a misuse of L2 system.

Adopted from Huang (2002), the procedure of the error analysis includes the following four steps:

- Data collection, usually from students' compositions;

- Identification of errors through the process of coding;

- Classification of errors into error types which might be grouped in accordance with the grammatical area (e.g. Errors in articles, errors in nouns, errors in verbs, etc.), the causing factors (L1 interference, overgeneralization, transfer of training, or communication strategy), or the characteristics of errors (global vs. local);

- A statement of error frequency

From the search of journal articles, an example of error analysis was found. This study is Lee and Chen (2009), conducted to find out the kind of errors learners typically make in their writings. This is an Error Analysis involving Contrastive Interlanguage Analysis (CIA) with the first corpus is the Chinese Academic Written English (CAWE), especially dissertations written by Chinese undergraduates majoring in English linguistics/applied linguistics. The second corpus is journal articles taken from a variety of high-ranking linguistics and applied linguistics journals with most of the articles selected to roughly match the topics of the Chinese learners' dissertations. The study reveals high frequency of 'the'; 'make'; 'besides'; 'can'; concordance of 'we can see' in CAWE (Chinese Academic Written English); concordance of TABLE/FIGURE in EXJA (Expert Journal Articles); and high frequency of 'according to'.

Another example is Haryanto (2007c). He conducted a study to find out the types of grammatical errors made by Indonesian EFL learners in English writing and the sources of their errors. Twenty eight pieces of compositions produced by students of English Department at Makassar State University were analyzed to find out two main features: the grammatical area where the learners make errors; and the factors that may cause the errors. A content analysis descriptive research method with qualitative data analysis technique was applied to seek for the answers to the proposed questions. As a result, the study reveals that from the most frequent to the least, grammatical errors occur in verb patterns, the passives, concord or agreement, nouns, tenses, articles, and others. From the perspective of causing factors, this study reveals that most grammatical errors were caused by two sources: first language interference and overgeneralization.

\section{4. $R \& D$}

$\mathrm{R} \& \mathrm{D}$ is a popular acronym for Research and Development. This is a kind of research method originally designed for business sector. Today, however, this method has attracted researchers in the teaching of English as a foreign language. University officers also approve this as a research method for dissertation, since this kind of method can potentially produce new products that meet today community's necessities. This is in line with the university vision and mission that is formulated to produce graduates with entrepreneurship spirit. A documentary analysis study at the Doctorate English Language Education Program has revealed the evidence that R \& D is a preferred research method. Five examples of studies making use of this method are Pongsapan et al (2016); Hasmiati et al (2015); Sunubi et al (2016); Latifa et al (2015); and Atmowardoyo et al (2017).

Pongsapan et al (2016) made use of R \& D to develop Instructional Materials for Nursing Students at Toraja, South Sulawesi, Indonesia. The study was designed to find out the language needs and the learning needs; and to develop ESP Speaking Course Material that meet the language and learning needs of the nursing students in Toraja. To achieve these three objectives, they conducted the research in three steps. First, they observed the existing ELT materials for nursing 
students. The result of this observation is used as the reasons for developing material for nursing students that meet the students' language need as well as their learning needs. These needs are formulated based on the needs analysis. The second step is designing the blueprint of the ELT materials; and finally, with the assistance of nursing experts and ELT experts as validates, the blueprint was used as the basis for developing the ELT materials. A book entitled English for Nurse was issued.

Hasmiati et al (2015) used R \& D to develop an English Course Book for high school students based on Curriculum 13 and local content materials. The research was carried out in several steps adapted from ADDIE model: analyzing the existing textbooks, conducting need analysis, designing the textbook blueprint, developing the prototype material, trying out the prototype through an experiment, and evaluating its effectiveness. As a result, an English textbook for Senior High School that incorporate local culture was issued.

Sunubi et al (2016) developed teaching and learning vocabulary material based on fishbone model for Islamic university students of English. The idea of developing vocabulary teaching and learning material was inspired by Ishikawa's idea stating that fishbone is a tool for analysis providing a systematic way of looking at effect and cause that create or contribute to those effects. This idea was combined with a learning theory involving mind mapping. In an attempt to develop the intended material, they applied ADDIE (analyze, design, develop, implement, and evaluate) in the development process. As a result, a newly developed vocabulary material under the topics Prophet Muhammad, Status of Woman, Lesson Life, and The Power of Istighfar was issued. With this, learners are encouraged to develop the related vocabulary through mind mapping in fish skeleton model.

Latifa et al (2016) used R \& D to develop a practical rating scale of speaking test for university students of English in Parepare, Indonesia. They started this study when they noticed that some available rubrics of speaking test are not well implemented in their experiential teaching and learning since they are too complicated. In an effort to develop a practical rubric, they proposed a new rubric, validated it, tested it, and revised it. A practical rubric was then issued.

The last, Atmowardoyo et al (2017) developed an instrument for assessing EFL teachers' performance based on the students' perception. The need and the absence of instruments to assess EFL teachers' performance have inspired them to develop valid and reliable instrument in the form of questionnaire. A two-level study was conducted. The first study is a qualitative research designed to capture as many as possible the qualities attributable to effective EFL teachers as well as those attributable for ineffective EFL teachers. A total number of 86 freshmen were assigned to report their experiences studying English with their favorite EFL teachers and with undesired EFL teachers in their high schools. This study revealed a number of competences attributable to effective EFL teachers; and those of ineffective ones. The second study was designed to develop an assessment instrument for EFL teachers' performance based on the students' perception. The results of the first study were manipulated into an instrument draft in the form of questionnaire with adapted Likert's scale. The draft is validated by experts in language teaching and educational measurements. Then, the draft was revised and tested to 100 high school students to find out the reliability index. The final product is a forty four-item questionnaire consisting of twenty positive statements and 24 negative statements with validity level of 0.98 and reliability index of 90.4. Thus, this study has revealed a valid and reliable instrument for assessing EFL teachers' performance based on the students' perception.

\section{CONCLUSION}

The study of research methods in TEFL Studies can actually reveal more methods such as discourse analysis, content analysis, narrative inquiry, and developmental study. However, due to the limited space, the writer can only present the four common methods: descriptive research, case study, and error analysis, and R \& D. The explanation of these four methods is expected to be beneficial for undergraduate or graduate students who are preparing a research for his or her thesis or dissertation. Learning from examples is sometimes simpler than from the theory. This is the reason why the writer presents this material in this way.

\section{ACKNOWLEDGEMENTS}

I would like to thank the following individuals or organizations who have me possible to publish this article. Firstly, Directorate of Higher Education who has facilitated me to join an academic recharging program in Ohio State University. Secondly, Dr. David Bloom, my counterpart in Ohio State University who has helped me find some important references. And thirdly, I highly appreciate the Rector of Universitas Negeri Makassar who has supported me to stay out of Makassar and write this article.

\section{REFERENCES}

[1] Agar, Michael. (2009). Notes from a professional speech delivered in a seminar at Ohio State University in December 2009.

[2] Asriati. (2015). A Study of Effective English Language Teachers at Senior High School Level in Makassar, ELT Worldwide 2.1, 63-79.

[3] Atmowardoyo, Haryanto. (2010). Research Methods for Language and Literature Studies, Makassar: Badan Penerbit Universitas Negeri Makassar.

[4] Atmowardoyo, Haryanto, Ja'faruddin, Khaerati. (2017). International Journal of Science and Research 7.6, 608-614. 
[5] Bade, Magaret. (2008). Grammar and Good Language Learners, in Griffith (ed.) Lesson from Good Language Learners; pp. 174-184.

[6] Basturkmen, Helen and Marilyn Lewis. (2002). Learner perspestives of success in EAP writing course. Assessing Writing 8; pp. 31-46, Elsevier.

[7] Brumfit, C.J. (2001). Individual freedom in language teaching: helping learners to develop a dialect of their own. Oxford: Oxford University Press.

[8] Corder, S. Pit, (1981). The significance of learners' errors' in International Review of Applied Linguistics, Oxford: Oxford University Press.

[9] Curtiss, Susan. (1977). Genie: A Psycholinguistic Study of a Modern-Day Wild Child, New York: Academic Press Inc.

[10] Ellis, Rod. (1997). Second Language Acquisition, Oxford: Oxford University Press.

[11] Griffiths, Carol. (2008). Strategies and good language learners, in Lessons from Good Language Learners. Cambridge: Cambridge University Press; pp.83-98.

[12] Haryanto. (1999). Motivation and Learning Strategy of a Good Language Learner in Indonesia: A case study toward a an effective English learners at a Senior High School. Unpublished Disertation, IKIP Jakarta.

[13] Haryanto. (2007a). Kajian tentang Pembelajar Bahasa Inggris yang Berhasil, Jurnal Humaniora, Universitas Hasanuddin 6.1, 71-77.

[14] Haryanto. (2007b). Motivasi dan Strategi dalam Pembelajaran Bahasa Asing, Jurnal Pancaran Pendidikan, Universitas Negeri Jember, 5.4, 140-148.

[15] Haryanto. (2007c). Grammatical Errors in Indonesian EFL Learners' Writing, A Paper, presented to the $5^{\text {th }}$ Annual of Linguistic Conference ( KOLITA 5) at Atmajaya Catholic University, Jakarta, 7-8 May 2007.

[16] Hasmiati, Arifuddin Hamra, Haryanto Atmowardoyo, Syarifuddin Dollah. (2015). Designing an English Course Book for High School Students Based on 2013 Curriculum with Local Content Materials, Journal of Language Teaching and Research 6.6, 1240-1249

[17] Hassal, Tim. (2003). Requests by Australian learners of Indonesian, Journal of Pragmatics V 3.5, 1903-1928.

[18] Hatifah, Nurul. (2017). The Successful Teacher's Verbal Cues in View of Interpersonal Communication to Lead EFL Adult Beginner Learner's Accuracy in Calling Interaction, ELT Worldwide 4.1, 114-123.

[19] Huang, J. (2002). Error analysis in English Teaching: A review of studies. Journal of Chung-San Girls' Senior High School 2, 19-34.

[20] Johnson, R. B. and Onwuegbuzie, Anthony J. (2007). Mixed Methods Research: A research paradigm whose time has come. Educational Researcher 33. 7, 14-26.

[21] Khaerati, Khaerati. (2016). The Students' Perception on the Characteristics of Effective and Ineffective English Language Teachers, ELT Worldwide 3.2, 221-230.

[22] Kikuchi, Keita. (2009). Listening to our learners' voices: what demotivates Japanese high school students?, Language Teaching Research 13. 4, 453-471.

[23] Latifa, Ammang, Asfah Rahman, Arifuddin Hamra, Baso Jabu, Rafi'ah Nur. (2015). Developing a Practical Rating Rubric of SpeakingTest for University Students of English in Parepare, Indonesia, English Language Teaching 8.6, 199-177.

[24] Lee, David Y.W. and Sylvia Xiao Chen. (2009). Making a bigger deal of the smaller words: Function words and other key items in research writing by Chinese learners, Journal of Second Language Writing 18, 149-165.

[25] Lee, Icy. (2007). Feedback in Hongkong secondary writing classroom: Assessment for learning or assessment of learning? Assessing Writing 12, 180-198.

[26] Miles, M., \& Huberman, A. M. (1994). Qualitative data analysis: An expanded sourcebook (2 ${ }^{\text {nd }}$ ed.). Thousand Oaks, CA: Sage

[27] Nixon, Rhonda \& Jill Kedersha McCay. (2007). Collaborative writing assessment: Sowing seeds for transformational adult learning, Assessing Writing 12, 149-166

[28] Nunan, (1999) Nunan, D. (1999). Seond language teaching and learning. Boston, MA: Heinle and Yale University Press.

[29] Onwuegbuzie, A. J. and Leech, N.L. (2006). Linking research questions to mixed methods data analysis procedures. The Qualitative Report 11. 3, 474-498.

[30] Pongsapan, Nehru P., M. Basri Wello, Baso Jabu. (2016). Developing Instructional Materials for Nursing Students at Toraja, South Sulawesi, Indonesia, Journal of Literature, Languages and Linguistics 23, 8-24.

[31] Richards, J.C. (1974). Error Analysis. London: Longman Group Ltd.

[32] Richards, J.C. (1990). The language teaching matrix. Cambridge: Cambridge University Press.

[33] Wette, Rosemary. (2009). Making the instructional curriculum as an interactive, contextualized process: case studies of seven ESOL teachers, Language Teaching Research 13. 4, 337-365.

[34] Strauss, Anselm and Juliet Corbin. (1990). Basics of Qualitative Research: Procedures and Techniques of Grounded Theory. New York: Sage Publication.

[35] Sunubi, Abdul H., Arifuddin Hamra, Baso Jabu. (2016). Journal of Language and Literature 7. 4,. 178-183.

[36] Wai King Tsang. (2004). Teachers' personal practical knowledge and interactive decisions, Language Teaching Research 8. 2 , 163-198.

[37] Weda, Sukardi. (2016). Students' Voice Toward Good English Teachers' Characteristics at Secondary Schools in Indonesia, ELT Worldwide 3. 1, 78-90. 
Haryanto Atmowardoyo was born in Purbalingga, 29 October 1959. He is currently a professor in English Language Education at Universitas Negeri Makassar. He completed his sarjana (bachelor) degree in 1985 with a thesis on Error Analysis entitled Grammatical Errors made the S1 Students of the English Department, IKIP Ujung Pandang. In 1994 he completed his Master degree in English Language Education with a thesis involving the use of Descriptive Research entitled Cohesion in Descriptive Discourse Written by the English Department Students of IKIP Ujung Pandang. In 1999, he conducted a case study research entitled Motivation and Learning Strategy of a Good EFL Learner in Senior High School for his Doctor degree at IKIP Jakarta. He has learned Qualitative Research Methodology from Professor Robert Bogdan of Syracuse University through a one-month workshop in Universitas Indonesia. He has also learnt much about research methodology from Dr. David Bloom and other experts from Ohio State University through a four-month academic recharging program in 2009-2010. 